\title{
The Impact of COVID-19 Pandemic on Global Stock Markets: An Event Study
}

\author{
Submitted 18/07/20, 1st revision 20/08/20, 2nd revision 11/09/20, accepted 10/10/20
Ibrahim N. Khatatbeh ${ }^{1}$, Mohammad Bani Hani ${ }^{1}$, Mohammed N. Abu-Alfoul ${ }^{2}$

\begin{abstract}
:
Purpose: This study aims to empirically examine the immediate reaction of affected countries' stock market indices to COVID-19.

Approach/Methodology/Design: The study applies an event study methodology using daily data series of stock price indices.

Findings: Evidence from eleven global stock market indices shows that the first confirmed COVID-19 case announcement has had a significant negative impact on the returns. Moreover, these effects were more substantial following the WHO announcement of COVID19 as a global pandemic on March 11, 2020.

Practical Implications: The rapidly developing outbreak of the COVID-19 pandemic has depressed the affected countries' economies and caused turmoil in global financial markets. The results presented in this paper shed some light on the potential economic and social cost of COVID-19 concerns policymakers and other stock market stakeholders.

Originality/value: The results suggest that stock markets have captured investors' expectations over potential adverse economic consequences of COVID-19. Moreover, there is evidence for an underreaction to the pandemic's announcement, as shown by the delayed response of stock markets in terms of significant CARs. These findings leave a wish list of topics for future research.
\end{abstract}

Keywords: COVID-19, stock markets, abnormal returns, event study.

JEL codes: G14, G15, E44.

Paper Type: Research article.

ISSN:

Acknowledgment: We thankfully acknowledge helpful comments from Professor Imad Moosa on an earlier version of this paper.

\footnotetext{
${ }^{1}$ Faculty of Economics and Administrative Sciences, The Hashemite University, Zarqa, Jordan, e-mail: ibrahim.khatatbeh@hu.edu.jo

${ }^{2}$ Faculty of Business and Law, Swinburne University of Technology, Melbourne, Australia
} 


\section{Introduction}

The outbreak of the novel coronavirus (COVID-19) has disrupted the affected countries' economic activities and become a real threat to the global economy and financial markets (Barro et al., 2020; Ramelli and Wagner, 2020). Most of the global stock markets have plunged, and international financial institutions have cut their growth forecasts for 2020 and beyond (Boone et al., 2020). COVID-19 was originated in Wuhan city, China, last December. Since then, the disease has spread exponentially and infected more than 2 million persons across 210 countries (WHO, 2020).

Accordingly, the WHO announced COVID-19 as a pandemic on March 11, 2020, (WHO, 2020). Numerous reports and policy briefs predict a horrendous impact of the COVID-19 crisis that is comparable to or worse than the Great Depression. Kristalina Georgieva, the managing director of the International Monetary Fund (IMF), stated, "We anticipate the worst economic fallout since the Great Depression" (WHO, 2020). Therefore, the unfortunate event of the COVID-19 outbreak provides an opportunity to assess the immediate impact of an unexpected disease outbreak on the affected countries' stock markets.

The objective of this paper is to investigate the impact of the COVID-19 pandemic on leading stock market indices for a group of the top affected countries. The sample countries are Belgium, China, France, Germany, Italy, The Netherlands, South Korea, Spain, Switzerland, United Kingdom, and the United States. Particularly, we examine the stock markets' immediate reactions to the announcement of the first confirmed case for each country. Moreover, we examine the stock market responses to the announcement of COVID-19 as a global pandemic by the WHO. The WHO announcement came from an increasingly widespread pandemic transmission to more than 110 countries at that time. This declaration is unusual, implying extra containment measures must be applied for the affected countries. Therefore, we expect significant negative abnormal returns in global stock markets following the WHO announcement. In addition, we are not sure whether the WHO announcement has a greater impact on the affected countries' stock markets, compared to the announcement of the first confirmed COVID-19 case confirmed in each country.

Our study is closely related to Nippani and Washer (2004), who examine the effects of the SARS (severe acute respiratory syndrome CoV-1) outbreak of 2003 on stock market indices of six affected countries by comparing these indices to the performance of the pre-event period and the S\&P 1200, using conventional t-tests and Mann-Whitney non-parametric tests. They find limited evidence of the negative impact of the SARS epidemic outbreak on China and Vietnam's stock market indices. The remainder of the paper is organized as follows. The potential economic consequences are explored in section 2. The data and methodology are presented in section 3. The empirical results are presented and discussed in section 4 . Finally, the conclusion can be found in section 5 . 


\section{The Impact of COVID-19 on Stock Markets and the Economy}

The COVID-19 pandemic is an unexpected shock to the global economy, with economic destruction on an unprecedented scale (Goodell, 2020). Generally, the COVID-19 is depressing the global economy; however, the outbreak's economic consequences are unequally distributed throughout the economy (Bloom et al., 2018; Guerrieri et al., 2020; Grima et al., 2020). While most industries will bear losses due to economic disruption, some industries are expected to benefit financially, i.e., pharmaceutical industries.

The COVID-19 pandemic has been called "the Great Lockdown," referring to the severe containment measures enforced due to the pandemic outbreak. Several international institutions downgraded their growth forecast due to the COVID-19 pandemic; for instance, the international monetary fund (IMF) has cut the global growth forecast of 2020 to $-3 \%$, down by $6.3 \%$ from early year projections (IMF, 2020). Similarly, the Organisation for Economic Cooperation and Development (OECD) expects a continued and prolonged outbreak of the coronavirus pandemic may decrease global economic growth by $1.5 \%$ for 2020 (OECD, 2020). Moreover, the Asian Development Bank (ADB) predicts the global cost of COVID-19 pandemic to top US\$4.1 trillion, which is more than 40 times the global cost of the SARS outbreak (2002-2003) estimates of US\$ 30-100 billion (Smith, 2006) (Thestar.com, 2020). Also, the International Labour Organization expect global unemployment would increase by approximately 25 million (ILO, 2020) (McKibbinand Fernando, 2020).

Bloom et al. (2018) were clairvoyant to show concerns about the potential emergences of economically damaging pandemics - such as various influenza types and other unknown pathogens - ahead of the COVID-19 outbreak. They list various economic risks resulting from pandemic/epidemic outbreak, including costs to the health system, loss to employee productivity, a decline in economic activity, a negative impact on tourism, and a negative impact on foreign direct investment (FDI). Many articles have considered the economic consequences of past epidemics and pandemics on the infected countries. However, the existing literature on the effects of epidemics and pandemics on financial markets is rather limited (Goodell, 2020). The COVID-19 pandemic comes at a larger scale-when compared to modern history pandemics. Nobel laureate Robert Shiller describes potential economic consequences of COVID-19 as "something we have not quite seen before." Detrixhe (2020) emphasizes that unlike the Great Depression-which can largely be attributed to a "pessimistic idea," the COVID-19 economic crisis results from a shock to the real economy, causing the economic activity to slow down deeply.

The pandemic effects could be transmitted to stock markets through several channels. For instance, the spread of contagious diseases induces a decline of economic activity and endures a major challenge for business profitability and continuity in extreme situations as lockdown (Adda, 2016). Moreover, a pandemic 
induced economic and financial shocks in one country spreads rapidly to others due to high levels of the interconnectedness of markets due to globalization and financial integration (Chen et al., 2018; Liu et al., 2020). Recently, Zhang et al. (2020) show that global financial markets volatilities have increased substantially due to the COVID-19 pandemic outbreak, and the magnitude of volatility commensurate with the severity of the outbreak in each country (Khan et al., 2020). They report significant increases in systemic risk between the affected countries, particularly following the WHO announcement of COVID-19 as a global pandemic. Also, other channels related to panic selling, profit-taking, and the search for more safe assets in times of crises (Lucey and Li, 2014).

Stock markets have long been considered relevant in forecasting real economic activity. Harvey (1989) argues that "the price of equity thus reflects expectations of real activity, and changes in the value of equity partially reflect revisions in these expectations." Thus, market participants' expectations reflected in stock prices could provide a perspective of growth prospects, given the unprecedented uncertainty on the COVID-19 pandemic (Gormsen and Koijen, 2020). Moreover, when an unexpected disastrous event happens, financial investors are induced to exit the unstable market, searching for more stable financial investments (Arin et al., 2008). In a recent study, Ramelli and Wagner (2020) examine stock prices' reactions to the COVID-19 event at the industry level, focusing on international supply chains. They find that US firms with greater trading or supply chain relations with China have experienced lower cumulative abnormal returns (CARs) following the confirmation of the virus's human-to-human transmission on January 20, 2020. They conclude that investors have become more concerned about the economic and financial consequences of the COVID-19 pandemic crisis.

\section{Methodological Procedures}

Daily data series of stock price indices were obtained from 'investing.com,' which comprise the leading stock price index for each sample country, as shown in Table 1. The data on the first confirmed COVID-19 cases are obtained from major news websites and validated with the COVID-19 database published by the European Centre for Disease Prevention and Control.

This study applies the standard event study methodology of Brown and Warner (1985) to test how stock markets react to the COVID-19 pandemic outbreak. The methodology suggested by Brown and Warner (1985) enables us to examine the significance of the economic impact of the COVID-19 outbreak on the affected countries' stock markets. To do this, we measure the deviation of the stock market index from their historical average. The event study analysis is based on the hypothesis that if the stock market index is affected by an event, the influence would be translated into abnormal returns - as stock prices immediately adjust to the announcement of new information (Fama et al., 1969). 
Table 1. Global Stock Market Indices Descriptive Summary

\begin{tabular}{|c|c|c|c|c|}
\hline \multirow[b]{2}{*}{ Country } & \multicolumn{3}{|c|}{ Index } & \multirow[b]{2}{*}{$\begin{array}{l}\text { Change } \\
(\%)\end{array}$} \\
\hline & Stock Market Index & Close Price 31/12/2019 & $\begin{array}{l}\text { Close Price }^{1} \\
24 / 03 / 2020\end{array}$ & \\
\hline Belgium & BEL 20 & $3,955.83$ & $2,867.59$ & $-27.51 \%$ \\
\hline China & $\begin{array}{l}\text { Shanghai composite } \\
\text { index }\end{array}$ & $3,050.12$ & $2,722.44$ & $-10.74 \%$ \\
\hline France & CAC 40 & $5,978.06$ & $4,242.70$ & $-29.03 \%$ \\
\hline Germany & DAX & $13,249.01$ & $9,700.57$ & $-26.78 \%$ \\
\hline Italy & FTSE MIB & $23,506.37$ & $16,948.60$ & $-27.90 \%$ \\
\hline Netherlands & AEX index & 604.58 & 461.73 & $-23.63 \%$ \\
\hline South Korea & KOSPI & $2,197.67$ & $1,609.97$ & $-26.74 \%$ \\
\hline Spain & IBEX 35 & $9,549.20$ & $6,717.30$ & $-29.66 \%$ \\
\hline Switzerland & Swiss market index & $10,616.94$ & $8,733.32$ & $-17.74 \%$ \\
\hline United Kingdom & FTSE 100 & 7542.44 & 5446.01 & $-27.80 \%$ \\
\hline United States & S\&P 500 & $3,230.78$ & $2,447.33$ & $-24.25 \%$ \\
\hline World Benchmark & MSCI world index & $2,358.47$ & $1,742.61$ & $-26.11 \%$ \\
\hline
\end{tabular}

${ }^{I}$ March24, 2020 is the end-date of the used sample.

Source: Own study.

Therefore, evidence of significant positive (negative) abnormal returns is expected if the markets react to the event favorably (unfavorably). The analysis commences by examining the reactions of the affected countries' stock market indices to the announcement of the first confirmed case for each country. Subsequently, we examine these indices' reactions to the announcement of COVID-19 as a pandemic by the WHO on March 11,2020 . The Abnormal returns $\left(A R_{i, t}\right)$ for index $\mathrm{i}$ at day $\mathrm{t}$ is calculated as in equation (1):

$A R_{i, t}=R_{i, t}-\bar{R}_{i, t}$

The actual daily returns $\left(R_{i, t}\right)$ is obtained by calculating the natural log of the price relative as in equation (2).

$R_{i_{2}, t}=\operatorname{Ln}\left(P_{i_{2}, t} / P_{i_{2}, t-1}\right)$

where $P_{i, t}$ is the close price of index $\mathrm{i}$ at day $\mathrm{t}$, and $P_{i_{3} t-1}$ is the close price of index $\mathrm{i}$ at day t-1.I The historical average of stock indices $\left(\bar{R}_{x, t}\right)$ is calculated using a 100 day estimation windowfor the period from the day $(-110)$ to the day $(-11)$, where the day (0) represents the event day - the announcement of the first confirmed COVID19 case for each country. In addition, we use equation (3) to calculate the cumulative abnormal returns $\left(C A R_{\left[t 1_{n}, t n\right]}\right)$.

$C A R_{\left[t 1_{1} t n\right]}=\Sigma_{t_{1}}^{t_{n}} A R_{i_{2} t}$

The CARs of 5-days and 10-days are calculated to show further the market's ability to rebound or further deteriorate for some trading days after the announcement day. Finally, the t-test statistics, the ratio of the average AR (CAR) to its estimated 
standard error, is calculated for the corresponding AR (CAR) - the null hypothesis is that $\mathrm{AR}(\mathrm{CAR})$ in the event window is equal to zero. Therefore, a significant test statistic implies that AR (CAR) is significant, which means that the announcement has been priced.

\section{Analysis of Results}

Table 2 reports the ARs and CARs (for 5 and 10 days) following the announcement of the first confirmed COVID-19 case(s) in each country. Of 11 major stock indices, 4 have significant negative ARs, 6 have significant negative CARs over the 5-days and 10-days event window. Interestingly, China has insignificant ARs and significant positive CARs following the first case confirmed on December 31, 2019; in our view, this might be due to the limited information about the nature of the virus and lack of containment measures applied until the lockdown of Wuhan city on January 23, 2020 - three days after the human-to-human transmission of the virus was confirmed. To check this, we calculate AR and CARs following January 21, 2020. The results show significant negative AR, 5-days CAR, and 10-Days CAR of $1.52 \%,-9.99 \%$, and $-6.69 \%$. Hence, the lockdown protocols, which have been applied later, have the most adverse effect on economic activity.

Table 2. Abnormal Returns (ARs) and Cumulative Abnormal Returns (CARs) of Global Stock Markets Indices Following the Announcement of the First Confirmed COVID-19 Cases

\begin{tabular}{llllllll}
\hline Country & $\begin{array}{l}\text { Date of First } \\
\text { Confirmed } \\
\text { Cases }\end{array}$ & AR\% & $\boldsymbol{t}$ (AR) & CAR5 \% & t(CAR5) & CAR10 \% & t(CAR10) \\
\hline Belgium & 4-Feb-20 & $1.27 \%$ & $2.59 * *$ & $2.45 \%$ & $22.84 * * *$ & $2.06 \%$ & $20.58 * * *$ \\
China & 31-Dec-19 & $0.31 \%$ & 0.41 & $0.77 \%$ & $3.87 * * *$ & $1.42 \%$ & $10.47 * * *$ \\
China & 21-Jan-20 & $1.52 \%$ & $2.10 * *$ & $9.99 \%$ & $-4.68 * * *$ & $-6.69 \%$ & $-6.58 * * *$ \\
France & 24-Jan-20 & $0.77 \%$ & 1.04 & $-3.41 \%$ & $-7.15 * * *$ & $-0.08 \%$ & -0.22 \\
Germany & 28-Jan-20 & $0.75 \%$ & 0.97 & $-0.33 \%$ & -0.59 & $1.49 \%$ & $3.39 * * *$ \\
Italy & 31-Jan-20 & $2.45 \%$ & $2.99 * *$ & $2.05 \%$ & $2.79 * *$ & $2.93 \%$ & $5.93 * * *$ \\
Netherlands & 28-Feb-20 & $3.84 \%$ & $4.79 * * *$ & $-5.80 \%$ & $-6.67 * * *$ & $-26.75 \%$ & $-8.47 * * *$ \\
South Korea & 20-Jan-20 & $0.41 \%$ & 0.55 & $-3.70 \%$ & $-4.23 * * *$ & $-5.24 \%$ & $-6.12 * * *$ \\
Spain & 1-Feb-20 & $0.29 \%$ & 0.39 & $4.05 \%$ & $9.17 * * *$ & $5.61 \%$ & $16.69 * * *$ \\
Switzerland & 26-Feb-20 & $0.21 \%$ & 0.32 & $-2.84 \%$ & $-3.73 * *$ & $-14.71 \%$ & $-9.67 * * *$ \\
United & 31-Jan-20 & $1.38 \%$ & $1.95 *$ & $0.72 \%$ & $1.87 * *$ & $-0.40 \%$ & $-1.72 * *$ \\
Kingdom & & $0.26 \%$ & 0.35 & $-1.60 \%$ & $-3.47 * *$ & $-0.93 \%$ & $-2.96 * * *$ \\
United States & 21-Jan-20 & 21 & & & \\
\hline
\end{tabular}

Notes: ${ }^{8}$ Repeated analysis for China (Shanghai composite index) considering January 21 , 2020 as the event date. ${ }^{\S}$ The event date Inspain coincidence with a weekend holiday, therefore, we take the abnormal return of the following trading day. CAR5 and CAR10 refer to 5-days CAR and 10-days CAR, respectively. The asterisks ***, **, * indicate significant test statistics at the 1\%, 5\%, 10\% levels, respectively.

Source: Own study.

Table 2 reports the ARs and CARs (for 5 and 10 days) following the announcement of the first confirmed COVID-19 case(s) in each country. Of 11 major stock indices, 4 have significant negative ARs, 6 have significant negative CARs over the 5-days and 10-days event window. Interestingly, China has insignificant ARs and 
significant positive CARs following the first case confirmed on December 31, 2019; in our view, this might be due to the limited information about the nature of the virus and lack of containment measures applied until the lockdown of Wuhan city on January 23, 2020 - three days after the human-to-human transmission of the virus was confirmed. To check this, we calculate AR and CARs following January 21, 2020. The results show significant negative AR, 5-days CAR, and 10-Days CAR of $1.52 \%,-9.99 \%$, and $-6.69 \%$. Hence, the lockdown protocols, which have been applied later, have the most adverse effect on economic activity.

Some stock markets have shown delayed response to the event, as revealed by insignificant ARs and significant negative CARs (i.e., France, South Korea, Switzerland, and the United States). This is to be taken as evidence for initial underreaction to the pandemic outbreak. Moreover, some distinctive patterns emerge for the remaining countries. For example, Belgium shows an underreaction to the first case's announcement, as shown by the positive AR and CARs; nevertheless, it has one of the highest and abnormal losses and cumulative abnormal loss following the WHO announcement.

Table 3. Abnormal Returns (ARs) and Cumulative Abnormal Returns (CARs) of Global Stock Markets Indices Following the WHO Announcemnt

\begin{tabular}{|c|c|c|c|c|c|c|c|c|}
\hline Country & $\begin{array}{l}\text { WHO } \\
\text { Announ } \\
\text { cement } \\
\text { Date }\end{array}$ & $\begin{array}{l}\text { Number of } \\
\text { Days since } \\
\text { the first case } \\
\text { confirmed }\end{array}$ & AR \% & $t(\mathbf{A R})$ & $\begin{array}{l}\text { CAR5 } \\
\%\end{array}$ & $\begin{array}{l}\text { t(CA } \\
\text { R5) }\end{array}$ & $\begin{array}{l}\text { CAR10 } \\
\%\end{array}$ & $\begin{array}{l}\text { t(CAR1 } \\
\text { 0) }\end{array}$ \\
\hline Belgium & & 36 & $-4.05 \%$ & $\begin{array}{l}-7.58 \\
* * *\end{array}$ & $-20.31 \%$ & $\begin{array}{l}-10.16 \\
* * *\end{array}$ & $-14.69 \%$ & $\begin{array}{l}-9.92 \\
* * *\end{array}$ \\
\hline China & & 71 & $-0.97 \%$ & -1.26 & $-9.48 \%$ & $\begin{array}{l}-7.34 \\
* * *\end{array}$ & $-7.66 \%$ & $\begin{array}{l}-8.24 \\
* * *\end{array}$ \\
\hline France & & 47 & $-0.66 \%$ & -0.8 & $-21.66 \%$ & $\begin{array}{l}-12.92 \\
* * *\end{array}$ & $-5.55 \%$ & $\begin{array}{l}-3.68 \\
* * *\end{array}$ \\
\hline Germany & & 43 & $-0.50 \%$ & -0.65 & $-22.49 \%$ & $\begin{array}{l}-13.07 \\
* * *\end{array}$ & $-7.58 \%$ & $\begin{array}{l}-4.89 \\
* * *\end{array}$ \\
\hline Italy & & 40 & $0.19 \%$ & 0.23 & $-17.55 \%$ & $\begin{array}{l}-14.20 \\
* * *\end{array}$ & $-5.11 \%$ & $\begin{array}{l}-3.47 \\
* * *\end{array}$ \\
\hline Netherlands & March & 12 & $-0.20 \%$ & -0.25 & $-18.73 \%$ & $\begin{array}{l}-14.05 \\
* * *\end{array}$ & $-2.93 \%$ & $\begin{array}{l}-2.01 \\
* *\end{array}$ \\
\hline South Korea & $\begin{array}{l}11, \\
2020\end{array}$ & 51 & $-2.94 \%$ & $\begin{array}{l}-3.81 \\
* * *\end{array}$ & $-21.71 \%$ & $\begin{array}{l}- \\
8.63 * \\
* *\end{array}$ & $-15.40 \%$ & $\begin{array}{l}-6.37 \\
* * *\end{array}$ \\
\hline Spain & & 39 & $-0.44 \%$ & -0.59 & $-17.94 \%$ & $\begin{array}{l}-12.49 \\
* * *\end{array}$ & $-8.35 \%$ & $\begin{array}{l}-7.21 \\
* * *\end{array}$ \\
\hline Switzerland & & 14 & $-0.58 \%$ & -0.88 & $-10.43 \%$ & $\begin{array}{l}-20.04 \\
* * *\end{array}$ & $-3.46 \%$ & $\begin{array}{l}-3.64 \\
* * *\end{array}$ \\
\hline $\begin{array}{l}\text { United } \\
\text { Kingdom }\end{array}$ & & 40 & $-1.48 \%$ & $-2.10 * *$ & $-16.39 \%$ & $\begin{array}{l}-16.43 \\
* * *\end{array}$ & $-5.44 \%$ & $\begin{array}{l}-4.65 \\
* * *\end{array}$ \\
\hline United States & & 50 & $-5.01 \%$ & $\begin{array}{l}-6.73 \\
* * *\end{array}$ & $-18.37 \%$ & $\begin{array}{l}-7.96 \\
* * *\end{array}$ & $-15.18 \%$ & $\begin{array}{l}-9.20 \\
* * *\end{array}$ \\
\hline $\begin{array}{l}\text { MSCI World } \\
\text { Index }\end{array}$ & & - & $-3.97 \%$ & $\begin{array}{l}-6.52 \\
* * *\end{array}$ & $-18.35 \%$ & $\begin{array}{l}-6.18 \\
* * *\end{array}$ & $-13.81 \%$ & $\begin{array}{l}11.84 \\
* * *\end{array}$ \\
\hline
\end{tabular}

Notes: CAR5 and CAR10 refer to 5-days CAR and 10-days CAR, respectively. The asterisks ***, **, * indicate significant test statistics at the 1\%, 5\%, 10\% levels, respectively.

Source: Own study. 
Moreover, the United Kingdom shows a volatile reaction to the announcement of COVID-19, as shown by the negative AR, positive 5-day CAR, and lastly, negative 10-day CAR. Besides, Germany shows significant positive CAR on the 10-day window, whereas Italy and Spain show positive CARs on the 5- and 10-day event windows. Similarly, the results of the ARs and CARs, following the announcement of COVID-19 as a global pandemic disease by the WHO, are shown in Table 3. It reveals that almost half of the sample countries experienced significant negative ARs on the event date. Subsequently, all countries experienced significant 5- and 10days CARs.

The results presented in Tables 2 and 3 suggest a delay in some stock market initial reaction to the first confirmed COVID-19 cases and the WHO announcements. The literature suggests several plausible explanations for the variation of stock market reaction to the pandemic outbreak:

1. Differences in market efficiency; Ramiah et al. (2012) theorize that stock markets would react "more leisurely" to announcements, in contrast to the efficient market hypothesis, positing that markets should instantaneously reflect all available information.

2. The investor's confidence in institutional infrastructure; Johnston and Nedelescu (2006) argue that differences in the magnitude and significance of the results might be attributed to the individual countries' authorities' responses to the pandemic investors' "trust" in their institutions' actions.

3. Ru et al. (2020) find that the countries that did not experience SARS in 2003 tended to underreact to the COVID-19 outbreak's announcement.

4. Some behavioral explanations suggest that delayed response may be attributed to behavioral anomalies such as disposition and mean reversion (Hirshlefier, 2015; Frazzini, 2006; Barberis et al.,1998).

The CARs of global stock markets reported in Table 3, following the WHO announcement, are generally more negative than their comparable values in Table 2. A comparison of the the10-day CARs for the sample countries are exhibited in Figure 1. Remarkably, countries with the highest 10-day CAR are located in Europe. This goes in line with the excessive pessimistic sentiment of European investors. For instance, a recent survey by the world economic forum-assessing opinions from 74 experts (from the United States and Europe) - shows that $62 \%$ of US exports and $82 \%$ of European experts expect a coronavirus-driven recession.

Overall, the evidence presented in this paper suggests that global stock markets have correctly anticipated the COVID-19 disastrous impact, as shown by the significant negative ARs and CARs, particularly following the WHO announcement. Moreover, these results are consistent with the journalistic and formal reports' tremendous negative sentiment, which proclaim the devastating consequences of COVID-19 on the global economy. 
Figure 1. 10-Days CARs Following the First Confirmed Case and the WHO announcements.

\section{Source: Own study.}

\section{Conclusion}

This paper provides empirical evidence on the immediate reactions of global stock markets to the unexpected outbreak of COVID-19 global pandemic, using an event study methodology. While it is too early to be certain of the pandemic effects, the results suggest that stock markets have captured investors' expectations over potential adverse economic consequences of COVID-19. Moreover, there is evidence for an underreaction to the pandemic's announcement, as shown by the delayed response of stock markets in terms of significant CARs. The findings of this paper leave a wish list of topics for future research. For instance, it would be worthwhile to investigate the pandemic's effect at a sectoral level for the affected countries - as the impact of the pandemic is unequally distributed (positively and negatively) across sectors (Bloom et al., 2018; Guerrieri et al., 2020). Moreover, it may be useful to examine whether the collapse of global stock markets results from contagion or local factors (e.g., COVID-19 outcomes: confirmed cases and deaths).

\section{References:}

Adda, J. 2016. Economic activity and the spread of viral diseases: Evidence from high frequency data, Quarterly Journal of Economics, 131(2).

Arin, P., Ciferri, D., Spagnolo, N. 2008. The Price of Terror: the Effects of Terrorism on Stock Market Returns and Volatility, Economics Letters, 101(3).

Barberis, N., Shleifer, A., Vishny, R. 1998. A Model of Investor Sentiment. Journal of financial economics, 49(3).

Barro, R., Ursúa, J., Weng, J. 2020. The Coronavirus and the Great Influenza Pandemic:

Lessons from the "Spanish Flu" for the Coronavirus's Potential Effects on Mortality and Economic Activity. NBER Working Paper, No 26866.

Binder, J. 1998. The Event Study Methodology Since 1969. Review of Quantitative Finance and Accounting, 11(2).

Bloom D.E., Daniel, C., Sevilla, J.P. 2018. Epidemics and economics: New and resurgent infectious diseases can have far-reaching economic repercussions. Finance and Development, 55(2), 46-49. 
Boone, L., Haugh, D., Pain, N., Salins, V. Boone, L. 2020. Tackling the fallout from COVID-19. In Baldwin, R. and di Mauro, B.W. (eds). 2020. Economics in the Time of COVID-19. A VoxEU.org Book, Centre for Economic Policy Research, London.

Brown, J., Warner B. 1985. Using Daily Stock Returns: The Case of Event Studies. Journal of Financial Economics, 14(1).

Chen, A., Siems, T. 2004. The Effects of Terrorism on Global Capital Markets. European Journal of Political Economy, 20(2).

Chen, M., Lee, C., Lin, Y., Chen, W. 2018. Did the SARS epidemic weaken the integration of Asian stock markets? Evidence from smooth time-varying cointegration analysis. Economic research-Ekonomskaistraživanja, 31(1).

Fama, E., Fisher, L., Jensen, M., Roll, R. 1969. The Adjustment of Stock Prices to New Information. International Economic Review, 10(1).

Frazzini, A. 2006. The Disposition Effect and Underreaction to News. Journal of Finance, 61(4).

Goodell, J. 2020. COVID-19 and Finance: Agendas for Future Research. Finance Research Letters.

Grima, S., Dalli Gonzi, R., Thalassinos, I.E. 2020. The Impact of COVID-19 on Malta and its Economy and Sustainable Strategies. Available at SSRN: https://ssrn.com/abstract=3644833 or http://dx.doi.org/10.2139/ssrn.3644833

Guerrieri, V., Lorenzoni, G., Straub, L., Werning, I. 2020. Macroeconomic Implications of COVID-19: Can Negative Supply Shocks Cause Demand Shortages? NBER Working Paper, No 26918.

Harvey, C. 1989. Forecasts of Economic Growth from the Bond and Stock Markets. Financial Analysts Journal, 45(5).

Hirshlefier, D. 2015. Behavioral Finance. Annual Review of Financial Economics, 7.

ILO. 2020. COVID-19 and the World of Work: Impact and Policy Responses. International Labour Organization (ILO) Notes, Genève.

IMF. 2020. World Economic Outlook, April.

Johnston, R., Nedelescu, O. 2006. The impact of terrorism on financial markets. Journal of Financial Crime, 13(1).

Khan, S., Rabbani, R.M., Thalassinos, I.E., Atif, M. 2020. Corona Virus Pandemic Paving Ways to Next Generation of Learning and Teaching: Futuristic Cloud Based Educational Model. Available at SSRN: https://ssrn.com/abstract=3669832.

Lucey, B., Li, S. 2014. What precious metals act as safe havens, and when? Some US evidence. Applied Economics Letters, 22(1).

McKibbin, W., Fernando, R. 2020. The Global Macroeconomic Impacts of COVID-19: Seven Scenarios, CAMA Working Paper, No 19-2020.

Nippani, S., Washer, K. 2004. SARS: A Non-Event for Affected Countries' Stock Markets? Applied Financial Economics, 14(15).

Ru, H., Yang, E., Zou, K. 2020. What Do We Learn from SARS-CoV-1 to SARS-CoV-2: Evidence from Global Stock Markets. SSRN Working Paper.

Smith, D. 2006. Responding to Global Infectious Disease Outbreaks: Lessons from SARS on the Role of Risk Perception, Communication and Management. Social science and medicine, 63(12).

WHO. 2020. Coronavirus disease (COVID-2019) situation reports-92, April 21.

Zhang, D., Hu, M., Ji, Q. 2020. Financial Markets Under the Global Pandemic of COVID19. Finance Research Letters. 